УДК 338.23

DOI: https://doi.org/10.37320/2415-3583/12.5

Мельник О.Г.

доктор економічних наук, професор, завідувач кафедри зовнішньоекономічної та митної діяльності, Національний університет «Львівська політехніка» ORCID: https://orcid.org/0000-0001-8819-1910

Приведа Р.Б. асистент кафедри зовнішньоекономічної та митної діяльності, Національний університет «Львівська політехніка» ORCID: https://orcid.org/0000-0003-1298-4134

\title{
ФОРМИ ТРАНСКОРДОННОГО СПІВРОБІТНИЦТВА В УКРАЇНІ: СТАН ТА ПЕРСПЕКТИВИ РОЗВИТКУ
}

У статті подано та охарактеризовано форми транскордонного співробітництва в Украӥні, такі як транскордонні кластери, транскордонні промислові парки/зони, єврорегіони, об' 'єнання єврорегіонального співробітництва, європейське об'єднання територіального співробітництва, транскордонне партнерство, прикордонна торгівля й транскордонні проєкти. Виокремлено особливості функиіонування в транскордонному просторі. Виявлено переваги та недоліки їх функціонування, оцінено сучасний стан розвитку транскордонного співробітництва на території України. Проведено аналізування теоретико-методологічних та практичних аспектів проблематики транскордонного співробітництва та його форм функціонування в наукових прачях вітчизняних авторів. У роботі також представлено принципи, на базі яких функціонують нові форми транскордонного співробітницттва, закони та нормативно-правові акти, щзо регулюють їх діяльність. В результаті дослідження авторами виокремлено найефективніші та перспективні форми транскордонного співробітництва на території Украӥни.

Ключові слова: транскордонне співробітництво, транскордонний простір, єврорегіональне співробітниuтвво, розвиток єврорегіонів, форми транскордонного співробітництва.

Постановка проблеми. В сучасних умовах транскордонне співробітництво відіграє важливу роль у соціально-економічному розвитку прикордонних територій України, адже в умовах європейської інтеграції розвиток регіонів та громад є пріоритетом для держави. Проте головними проблемами в розвитку транскордонного співробітництва на території України залишаються проблеми участі в реалізації проєктів та програм 
транскордонного співробітництва, високі бар'єри на законодавчому рівні щодо партнерства України в різних формах транскордонного співробітництва.

Аналіз останніх досліджень і публікацій. Дослідженнями проблематики транскордонного співробітництва та його форм функціонування займались такі вітчизняні науковці, як I.В. Артьомов, В.В. Гоблик, М.І. Долішній, Н.О. Діус, В.П. Приходько, Н.А. Мікула, I.P. Тимечко, С.I. Устич [1-5].

Мета статті полягає в аналізі форм транскордонного співробітництва, що функціонують на території України, характеристиці їх стану та перспектив подальшого розвитку.

Виклад основного матеріалу. Відповідно до Закону України «Про транскордонне співробітництво» метою транскордонного співробітництва $\epsilon$ формування добросусідських відносин і поглиблення взаємодії суб'єктів та учасників транскордонного співробітництва, що сприяє спільному вирішенню завдань місцевого та регіонального розвитку [6]. Суб'єктами транскордонного співробітництва можуть бути територіальні громади, органи місцевого самоврядування України, що взаємодіють із відповідними органами сусідніх держав у межах угод про транскордонне співробітництво. Учасники транскордонного співробітництва - це фізичні або юридичні особи, об’єднані територіальні громади, що безпосередньо беруть участь у транскордонному співробітництві.

Безумовно, нині транскордонне співробітництво $\epsilon$ важелем щодо розвитку прикордонних регіонів, що створює сприятливе підгрунтя для вирішення соціально-економічних проблем, які присутні в прикордонних регіонах, та посилює інтеграційні процеси України в Свропейський Союз.

Метою державної політики України щодо розвитку транскордонного співробітництва $\epsilon$ створення нових форм транскордонного співробітництва задля ефективнішого функціонування та управління процесами такого співробітництва. Нові форми транскордонного співробітництва зображені на рис. 1.

Згідно 3 рис. 1 транскордонне співробітництво в Україні має 8 форм, усі вони функціонують у транскордонному просторі, а транскордонні кластери, транскордонні промислові парки/зони, єврорегіони, ОСС, ЄОТС та транскордонне партнерство здійснюють свою діяльність у транскордонному регіоні. Варто детальніше охарактеризувати всі форми транскордонного співробітництва, щоб виокремити спільні риси та відмінності у функціонуванні кожного 3 них.

Транскордонний кластер є однією 3 нових форм транскордонного співробітництва, що поєднує учасників та суб'єктів транскордонного співробітництва у добровільній формі, які розміщені у транскордонному просторі. Транскордонний кластер входить до транскордонного регіону, адже розви- ток такої форми транскордонного співробітництва підтримується Європейським Союзом у межах реалізації регіональної політики, де першочерговою умовою $\epsilon$ стратегія спільного розвитку транскордонних регіонів. Особливістю транскордонного кластеру є те, що він формується на базі встановлених транскордонних взаємозв'язків між суб'єктами та учасниками такого співробітництва в різних сферах господарської діяльності, метою яких є підвищення економічного розвитку прикордонних територій.

Перевагами формування транскордонних кластерів $є$ тісна співпраця у сфері виробництва й промисловості, зниження трансакційних витрат, підвищення інвестиційної привабливості регіону, розвиток інноваційної діяльності та залучення додаткових фінансових ресурсів.

Створення транскордонних промислових парків/ зон має на меті розвиток підприємницької діяльності, забезпечення конкурентоспроможності підприємств у транскордонному регіоні та залучення прямих іноземних інвестицій у розвиток бізнесу. Характерною ознакою транскордонних промислових парків/зон $\epsilon$ наявність головного підприємства, навколо якого розвиваються та функціонують інші суб'єкти господарської діяльності.

Єврорегіон - це одна з організаційних форм транскордонного співробітництва, що функціонує на базі укладених двосторонніх або багатосторонніх угод про транскордонне співробітництво. Сврорегіони здійснюють свою діяльність на постійній основі, мають власні фінансові, технічні й адміністративні ресурси, мають право приймати та ухвалювати власні рішення, його географічне розташування залежить від ступеня соціально-економічної інтеграції. Єврорегіони поділяються на ті, що сформовані на прикордонних тери-

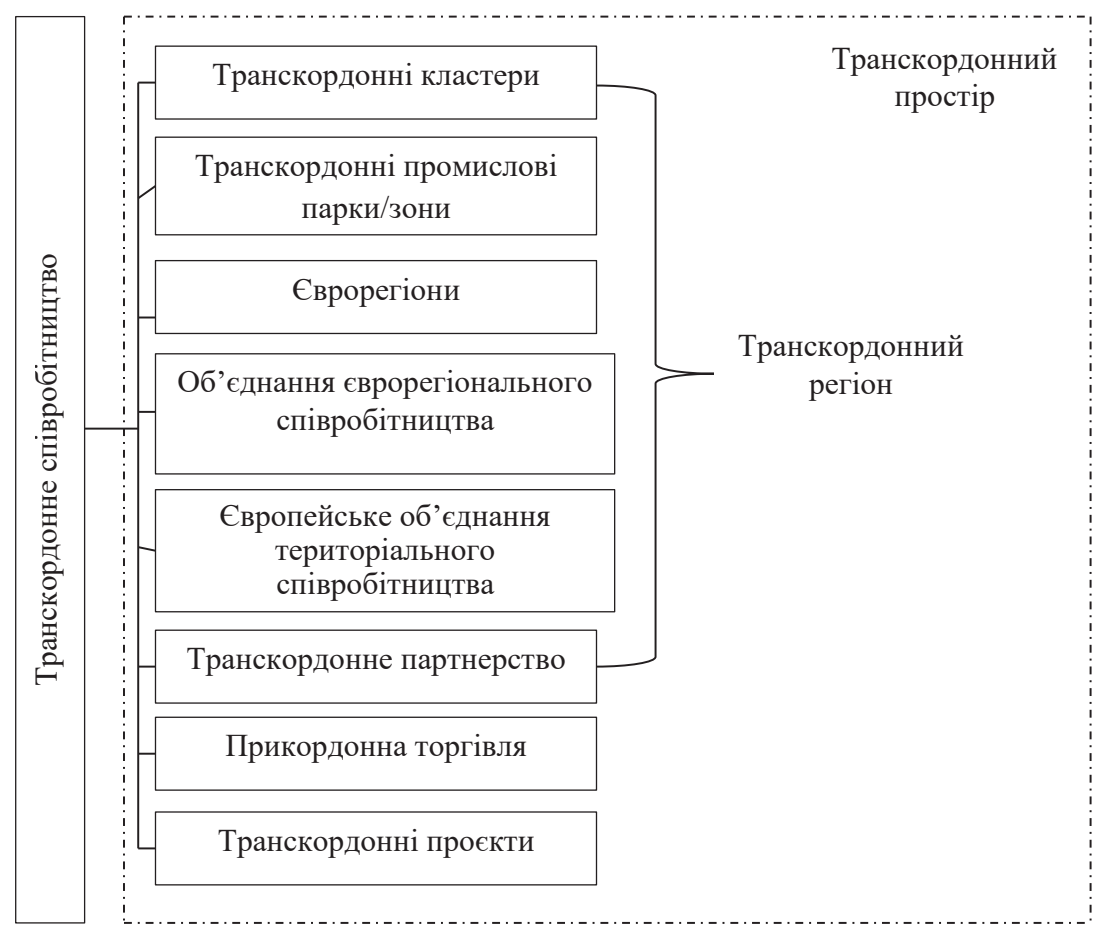

Рисунок 1 - Форми транскордонного співробітництва в Україні 
торіях країн-членів Свропейського Союзу, і країн-сусідів вздовж спільного кордону; утворені на території країн, що не входять до Свропейського Союзу. Отже, варто підкреслити, що транскордонне співробітництво вздовж західних кордонів України не обмежується, а єврорегіональна співпраця є одним з основних важелів щодо розвитку інтеграційних процесів держави в напрямах економіки, охорони навколишнього середовища, інфраструктури, освіти, культури та науки.

Спираючись на вищезазначені факти, можемо сказати, що створення єврорегіону $є$ інструментом що регулює та активізує транскордонне співробітництво в Україні, забезпечує пошук нових ефективних шляхів взаємодії органів місцевого самоврядування, об'єднаних територіальних громад, науково-дослідних інститутів та інших учасників транскордонного співробітництва по обидва боки кордону.

Згідно з чинним законодавством України формування єврорегіонів передбачає створення власної організаційної структури та системи фінансування у формі міжнародних міжрегіональних асоціацій, об'єднань, консорціумів тощо. Ефективна діяльність єврорегіонів на території України досягається лише за наявності спільних проблем між країнами-сусідами. В результаті цього кожен єврорегіон має конкретні пріоритети та напрями транскордонного співробітництва.

Єврорегіони різняться між собою за організаційною структурою, проте $є$ декілька таких спільних рис:

- наявність спільного секретаріату, адміністративного персоналу та експертів;

- статут єврорегіону, відповідно до якого він формується та функціонує;

- наявність хоча б одного керівного органу, що відповідає за прийняття управлінських рішень, членами якого є всі учасники єврорегіону.

Зазвичай організаційна структура єврорегіону складається 3 таких органів, як рада єврорегіону, голова управління, секретаріат та робочі комісії, які належать до певної сфери діяльності. Неодноразово у структурі зустрічається спільний моніторинговий комітет, до складу якого входять представники органів влади учасників єврорегіону та представники Європейського Союзу. Напрями діяльності єврорегіонів зображені на рис. 2.

Окрім єврорегіонів, існують інші форми транскордонного співробітництва, такі як об'єднання єврорегіонального співробітництва (ОСС) та європейське об’єднання територіального співробітництва (СОТС). Відповідно до Закону України «Про транскордонне співробітництво» об'єднання єврорегіонального співробітництва - це «форма транскордонного співробітництва зі статусом юридичної особи відповідно до національного законодавства держави, на території якої $є$ його місцезнаходження, метою якого $є$ заохочення, підтримка та розвиток в інтересах населення транскордонного та міжтериторіального співробітництва між суб'єктами і учасниками таких відносин у сферах спільної компетенції та відповідно до повноважень, встановлених згідно 3 національним законодавством відповідної держави» [1].

Основними характеристиками об'єднання єврорегіонального співробітництва $€$ такі:

- володіє статусом юридичної особи;
Підтримка регіонального розвитку

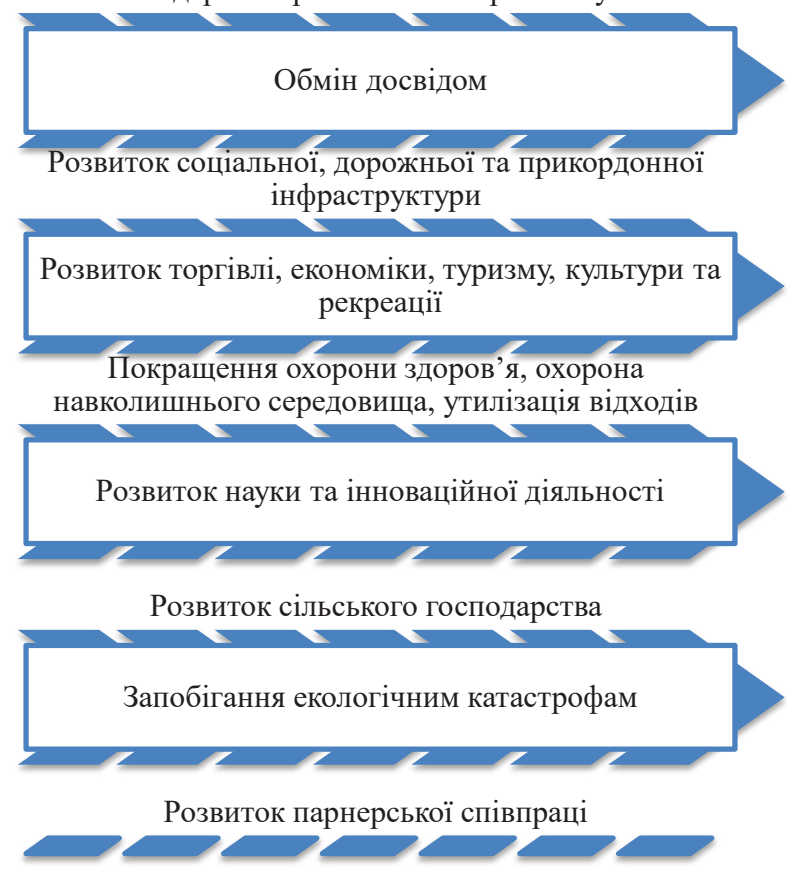

\section{Рисунок 2 - Напрями діяльності сврорегіонів}

Джерело: сформовано авторами

- функціонує як неприбуткова організація;

- виступає інструментом Ради Свропи;

- членами ОСС є об'єднані територіальні громади та їх представництва, місцеві органи виконавчої влади, держави-члени Ради Свропи, які діють задля задоволення потреб та загальних інтересів населення і не займаються комерційною чи виробничою діяльністю;

- зареєстровані лише в державі, яка є членом Ради Європи.

Нормативно-правову базу для створення й функціонування ОСС на території України становлять національне законодавство країни, де зареєстровано об'єднання; Протокол № 3 до Мадридської конвенції щодо транскордонного співробітництва між територіальними общинами та владами щодо об'єднань єврорегіонального співробітництва; Закон України «Про внесення змін до деяких законів України щодо транскордонного співробітництва». Письмова угода та статут $є$ юридичною основою діяльності ОЄС. У письмовій угоді містяться перелік членів ОСС, назва, цілі та завдання, які вирішуватиме ОСС, термін діяльності та його географічні масштаби впливу. У статуті зазначено правила щодо включення до членства в ОСС, виходу або його розпуску, правові наслідки в разі завершення співпраці, права та обов'язки органів ОСС, бюджет та джерела фінансування об'єднання.

Європейське об'єднання територіального співробітництва - це «об'єднання суб'єктів транскордонного співробітництва України та відповідних суб'єктів сусідніх держав - членів Свропейського Союзу зі статусом юридичної особи відповідно до національного законодавства держави - члена Свропейського Союзу, на території якої $\epsilon$ його місцезнаходження» [1]. Метою такого об'єднання є спрощення та сприяння транскор- 
донного співробітництва задля покращення економічного та соціального розвитку Європи. Діяльність ЄОТС має безліч переваг для розвитку транскордонного співробітництва, зокрема:

- СОТС можуть виступати як незалежна сторона в процесуальних діях;

- можуть володіти майном чи набувати його;

- мають право наймати штат працівників;

- можуть створюватись для вирішення одного конкретного завдання, а тоді припиняють своє функціонування;

- ухвалення рішень в СОТС відбувається швидко та ефективно;

- виступають єдиним бенефіціаром фінансування для реалізації проєктів та ініціатив СС.

СОТС відрізняється від ОСС тим, що воно є інструментом діяльності Європейського Союзу та регулюється законодавством держави, яка є членом ЄС. Масштаби діяльності СОТС мають більш локальний характер, ніж масштаби діяльності ОЄС, тому прийняття рішень та швидкість вирішення наявних проблем є значно ефективнішими. Учасники СОТС мають бути як мінімум 3 двох країн, одна 3 яких є членом Європейського Союзу. Відповідно, залучення коштів з СС на реалізацію проєктів транскордонного співробітництва відбувається за спрощеною системою через відповідність європейським стандартам ведення бухгалтерського обліку.

Перелік нормативно-правових актів, що регулюють діяльність ЄОТС, дещо відмінний від ОСС, наприклад основу їх діяльності складають Постанова Свропейського Парламенту та Ради Європи щодо Європейських об'єднань територіального співробітництва (СОТС) від 5 липня 2006 р. № 1082/2006 та Постанова Європейського Парламенту та Ради Свропи від 17 грудня 2013 р. № 1302/2013, що доповнює Постанову № 1082/2006 щодо Європейських об’єднань територіального співробітництва (СОТС) задля уточнення, спрощення та покращення процедури заснування й функціонування таких об'єднань [2]. Також кожна країна Свропейського Союзу має прийнятий документ національного законодавства що регулює питання щодо заснування та діяльності іiі учасників в рамках ЄOTC, тому що ЄОТС може бути зареєстрованим виключно на території держави-члена СС. Діяльність СOTC на території нашої держави регулює Закон України «Про внесення змін до деяких законів України щодо транскордонного співробітництва», де вищезазначене об'єднання закріплено як суб'єкт транскордонного співробітництва.

Юридичної базою заснування ЄОТС є угода про заснування й статут. В угоді про заснування міститься така інформація: назва та юридична адреса СОТС; територія, на яку поширюються його завдання; мета, ціль і завдання діяльності об'єднання; термін та умови функціонування чи припинення діяльності СОТС; перелік учасників, а також його органів та їх повноваження; законодавство СС та держави-члена СС; відповідальність, яку несуть СОТС та його члени. У статуті детально зазначено інформацію про повноваження органів та кількість представників-учасників СОТС в цих органах; процедуру ухвалення управлінських рішень; робочу мову чи мови СОТС; процедуру управління персоналом та правила набору на посади; процедуру формування бюджету, сплати фінансових внесків, проведення бухгалтерського обліку та звітності.

На кінець 2018 р. функціонуючих європейських об'єднань територіального співробітництва налічувалось близько 72. В Європі існують три основні райони, де зосереджено найбільшу частину СОТС, а саме Центральна Європа (Угорщина та країни-сусіди), Західна Європа (Бельгія, Німеччина, Франція, Нідерланди, Люксембург) і Середземномор'я (Греція, Італія, Португалія, Іспанія, Кіпр і Словаччина). Найактивнішими країнами, які $\epsilon$ ініціаторами створення таких об'єднань, є Угорщина, Франція, Іспанія, Словаччина, Італія й Німеччина. Середній бюджет кожного СОТС за 2011-2019 рр. представлено на рис. 3.

Аналізуючи рис. 3 , бачимо, що позитивна тенденція нарощення обсягів бюджету на діяльність СОТС спостерігається у 2017-2019 рр., найменше значення фінансування бюджету СОТС становило 320 тис. євро у 2012 р., а максимального значення досягнуто у 2019 р., а саме 650 тис. євро.

Закарпатська область України у 2015 р. стала членом СОТС «Тиса» 3 угорськими партнерами. Метою ЄОТС «Тиса» $\epsilon$ сприяння транскордонному співробітництву між іiї членами для посилення економічної, соціальної та територіальної згуртованості. Головними завданнями СОТС «Тиса» $є$ генерування та реалізація проєктів і програм транскордонного співробітництва для досягнення розвитку в економічній та соціальній сферах. Основним напрямом діяльності цього об'єднання є захист навколишнього середовища. Нині ЄОТС «Тиса» реалізує свої проєкти в рамках Програми транскордонного співробітництва Свропейського інструменту сусідства «Угорщина - Словаччина Румунія - Україна».

Існує декілька типів європейських об’єднань територіального співробітництва, вони утворились відповідно до географічного розташування та масштабу діяльності (табл. 1).

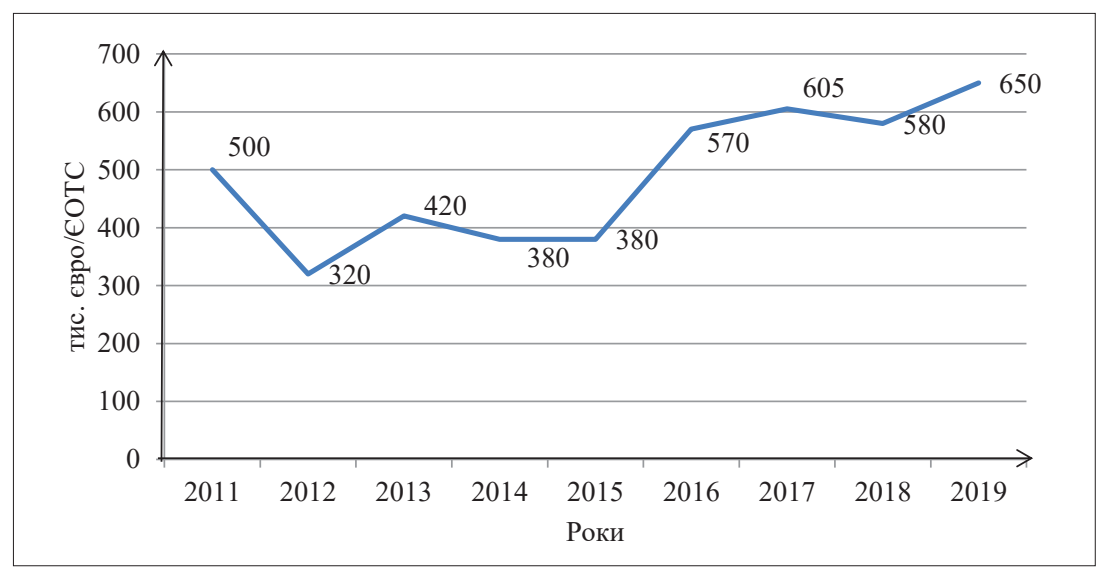

Рисунок 3 - Середній бюджет СОТС за 2011-2019 pp. 
Отже, транскордонні ЄОТС націлені на розвиток та реалізацію проєктів, що належать до сфери транскордонного співробітництва й мають обмежену кількість учасників, більшість яких складають органи місцевої влади, регіональні органи влади, а в деяких проєктах беруть участь навіть органи державної влади. Транснаціональні СОТС мають безліч учасників з різних країн, їх сфера діяльності охоплює велику територію та має на меті поглиблення інтеграційних процесів, що стимулюють територіальний розвиток. Мережеві ЄОТС об'єднують різні країни та регіони, які не формуються відповідно до їх географічного розташування. Більшість мережевих СОТС створюється задля вирішення вузькопрофільних завдань або підвищення привабливості конкретної сфери діяльності їх учасників.

Формування СОТС переважно проходить такі етапи, як підготовчий, технічний та операційний. Детальний опис етапів формування СОТС відображено на рис. 4.

Вищезазначені етапи формування СОТС характерні для країн-членів Європейського Союзу. Для України деякі з етапів формування СОТС будуть залучати додаткові заходи. Наприклад, перший етап потребуватиме більш детальної інформації щодо можливостей та цілей об'єднання, представлення кращих практик СОТС у Європі та прогнозування перспектив їх адаптації в Україні. На третьому етапі формування СОТС погодження статуту та угоди в Україні, згідно з чинним

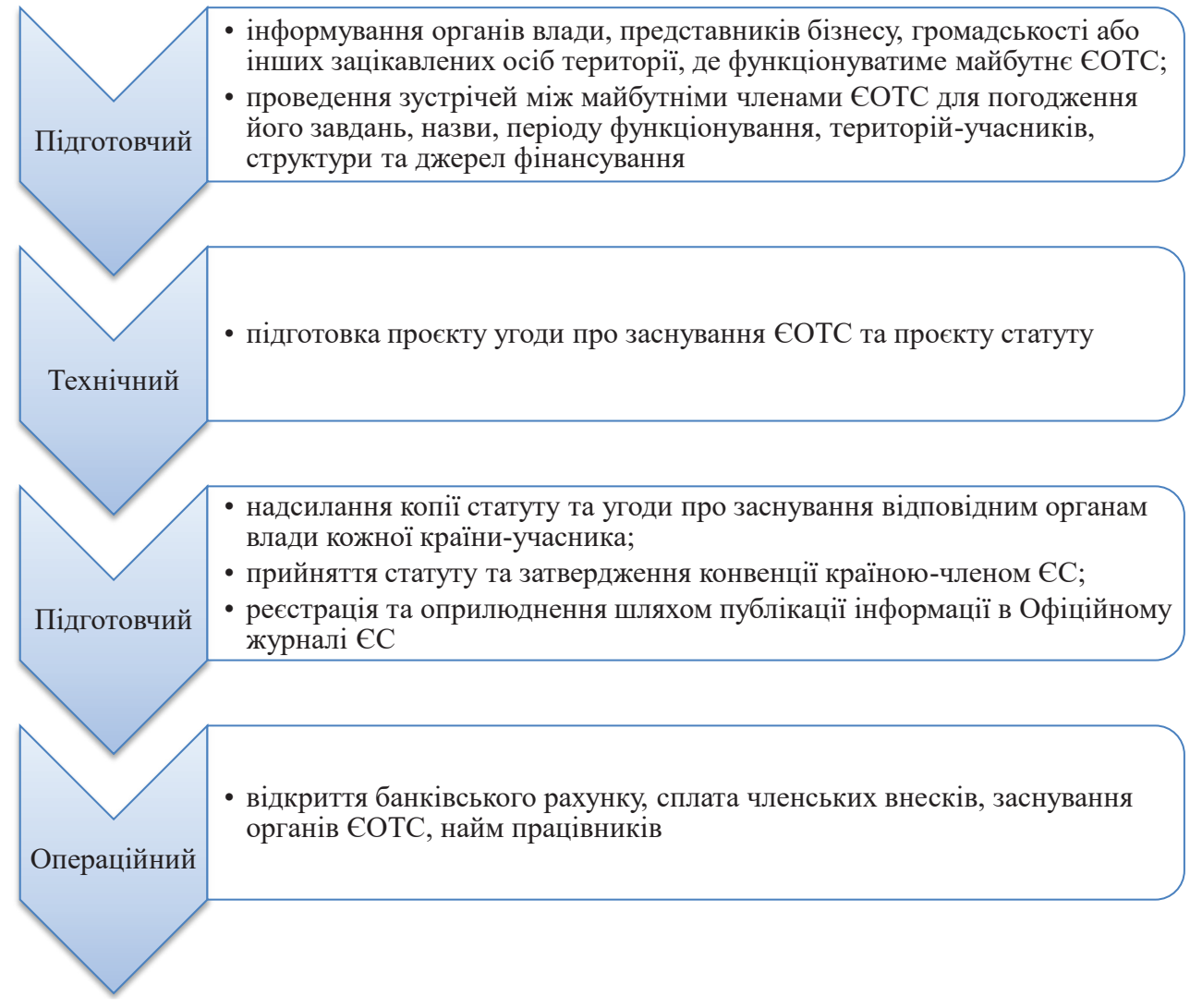

Рисунок 4 - Етапи формування СОТС у Свропі

Джерело: сформовано авторами на основі джерела [8]

Таблиця 1 - Типи європейських об'єднань територіального співробітництва

\begin{tabular}{|l|l|}
\hline \multicolumn{1}{|c|}{ Тип } & \multicolumn{1}{c|}{ Характеристика } \\
\hline Транскордонні СОТС & $\begin{array}{l}\text { Орієнтуються на вирішення питань місцевого чи регіонального рівня. Значну частину СОТС } \\
\text { складають транскордонні. Більшість транскордонних ЄОТС має учасників на рівні місцевих та } \\
\text { регіональних органів влади. У деяких транскордонних СОТС учасниками є центральні органи } \\
\text { державної влади. }\end{array}$ \\
\hline Транснаціональні СОТС & $\begin{array}{l}\text { Функціонують на великій території та налічують учасників із багатьох країн. Наприклад, СОТС } \\
\text { «Міжнародний альянс Рейн-Альпійського коридору» заснований задля зміцнення та координації } \\
\text { територіального та інтегрованого розвитку Рейн-Альпійського коридору. }\end{array}$ \\
\hline Мережеві СОТС & $\begin{array}{l}\text { Стимулюють співробітництво між регіонами, які неє близькими за географічним розташуванням. } \\
\text { Наприклад, СОТС «Асоціації міст - виробників кераміки» об’єднує асоціації виробників } \\
\text { кераміки Іспанії, Італії, Франції та Румунії. Вищезазначене ЄОТС реалізує проєкти у сфері } \\
\text { просування продукції та використання нових методів виробництва, стимулює обмін досвідом } \\
\text { митців задля підвищення ї професійного рівня та організовує міжнародні заходи. }\end{array}$ \\
\hline
\end{tabular}

Джерело: сформовано авторами на основі джерела [8] 
Законом «Про транскордонне співробітництво», виконуватимуть центральні органи виконавчої влади, до компетенції яких належать питання транскордонного співробітництва.

Незважаючи на вжиття додаткових заходів, брати участь у формуванні СОТС для України є важливим кроком в умовах європейської інтеграції, адже участь у СОТС - це великий досвід у розвитку транскордонного співробітництва, відкриття нових можливостей, залучення додаткових джерел фінансування в проєкти, які стосуються пріоритетних сфер економіки, промисловості, культури та освіти, тому надалі варто об'єднувати спільні зусилля 3 країнами-учасницями Європейського Союзу задля розвитку та поглиблення інтеграційних процесів України.

Наступною формою транскордонного співробітництва, що функціонує в транскордонному регіоні, є транскордонне партнерство. Транскордонне партнерство здійснює свою діяльність на основі добровільного об'єднання зусиль двох або більше територіальних громад, їх представницьких органів, громадських організацій, місцевих органів виконавчої влади, юридичних або фізичних осіб з різних боків кордону. Таке партнерство функціонує на засадах укладеного статуту чи рамкової угоди задля виконання спільних проєктів та програм транскордонного співробітництва, що стосуються вирішення соціальних, наукових, освітніх та культурних завдань.

На противагу попереднім формам транскордонного співробітництва, що функціонують у транскордонному регіоні, прикордонна торгівля та транскордонні проєкти реалізуються в транскордонному просторі. Прикордонна торгівля - це зовнішня торгівля, яка функціонує за принципами ринкової економіки та здійснюється юридичними й фізичними особами, що зареєстровані на прикордонній території, задля отримання власної економічної вигоди чи задоволення потреб населення через транскордонні ринки відповідно до міжнародних торговельних угод. Характерною особливістю прикордонної торгівлі серед інших форм транскордонного співробітництва $є$ чутливість до змін у бізнес-середовищі, наприклад мобільність процесів господарської діяльності до збільшення або зменшення розміру ставок мит, коливання цін на аналогічні товари на прикордонних територіях суміжних держав, введення нових вимог щодо перетину державного кордону власним транспортом. Щоби прикордонна торгівля була ефективною для України, необхідно активно розвивати цю форму транскордонного співробітництва з боку держави та укладати нові торговельні угоди 3 країнами-сусідами щодо спрощення зовнішньої торгівлі товарами, послугами та пересування громадян через кордон.

Транскордонні проєкти - це форма транскордонного співробітництва у сфері інновацій, мета створення яких зосереджена на покращенні конкурентоспроможності регіонів в інноваційній сфері та розробленні інноваційних стратегій. Впровадження інноваційних стратегій у межах транскордонних проєктів - це комплекс взаємопов'язаних дій та заходів, що забезпечують міжрегіональну співпрацю у науково-дослідних і дослідницько-конструкторських роботах між регіонами різних країн. Така форма транскордонного співробітництва є ефективною лише тоді, коли інноваційний розвиток населення та його розроблення має високий рівень. В Україні інноваційний розвиток населення перебуває на високому рівні, проте ефективність розробок та інновацій недоцільна через те, що мають низький рівень практичного використання й впровадження у господарську діяльність суб' єктів економіки.

Висновки. Підбиваючи підсумки, маємо виокремити найефективніші та перспективні форми транскордонного співробітництва на території України, а саме єврорегіони, об'єднання єврорегіонального співробітництва (ОСС) та європейське об'єднання територіального співробітництва (СОТС). За допомогою вищезазначених форм в Україні розвивається транскордонне співробітництво, реалізуються проєкти та програми, налагоджуються економічні зв'язки 3 країнами-сусідами, відбуваються інтеграційні процеси до включення держави в Європейський Союз. Кожна з цих форм має певні переваги та недоліки, проте перспективи їх функціонування є досить надійними для України та розвитку іiї регіонів і прикордонних територій. Для держави залишається тримати курс на Європейський Союз, запозичувати досвід у сфері транскордонного співробітництва, розробляти проєкти та підтримувати державний регіональний розвиток на високому рівні.

Список використаних джерел:

1. Артьомов І.В. Транскордонне співробітництво в євроінтеграційній стратегії України. Серія «Євроінтеграція: український вимір» : монографія. Ужгород : Ліра, 2009. 520 с.

2. Гоблик В.В. Роль єврорегіонів у розвитку економічного співробітництва прикордонних регіонів України та країн-членів ЄС. Економіка та держава. 2015. № 7. С. 14-17.

3. Долішній М.I. Регіональна політика на рубежі XX - XXI століть: нові пріоритети : монографія. Київ : Наукова думка, 2006. $511 \mathrm{c}$.

4. Мікула Н.А. Єврорегіональне співробітництво в системі транскордонної співпраці. Соціально-економічні проблеми сучасного періоду Украӥни. 2014. № 4. С. 28-38.

5. Тимечко І.Р. Організаційно-економічне забезпечення розвитку прикордонної торгівлі : автореф. дис. ... канд. екон. наук : спец. 08.00.05 ; Інститут регіональних досліджень НАН України. Львів, 2010. 24 с.

6. Про транскордонне співробітництво : Закон України від 24 червня 2004 р. № 1861-IV/ Верховна Рада України. URL: https://zakon.rada.gov.ua/laws/show/1861-15 (дата звернення: 15.05.2020).

7. EGTS monitoring report 2018-2019. European Committee of the Regions. URL: https://portal.cor.europa.eu/egtc/ressources/ Documents/CoR-EGTC-monitoring-report-final-study-2019.pdf (дата звернення: 10.05.2020).

8. Інформаційний бюлетень «Інструменти економічного розвитку місцевих громад: кращі європейські практики у сфері транскордонного співробітництва». Серія 1. Сврорегіони, ОСС, СОТС. URL: http://ird.gov.ua/irdp/p20190035.pdf (дата 3вернення: 21.04.2020). 


\section{References:}

1. Artjomov I.V. (2009) Transkordonne spivrobitnyctvo v jevrointeghracijnij strateghiji Ukrajiny [Cross-border cooperation in Ukraine's European integration strategy]. Serija “Jevrointeghracija: ukrajinsjkyj vymir" [European Integration: Ukrainian Dimension Series]. Uzhghorod : Lira, $520 \mathrm{pp}$.

2. Ghoblyk V.V. (2015) Rolj jevroreghioniv u rozvytku ekonomichnogho spivrobitnyctva prykordonnykh reghioniv Ukrajiny ta krajin-chleniv JeS [The role of Euroregions in the development of economic cooperation between the border regions of Ukraine and EU member states]. Ekonomika ta derzhava. № 7, pp. 14-17.

3. Dolishnij M.I. (2006) Reghionaljna polityka na rubezhi XX - XXI stolitj: novi priorytety [Regional policy at the turn of the XX XXI centuries: new priorities]. Naukova dumka [Scientific thought]. Kyiv, pp. 511.

4. Mikula N.A. (2014) Jevroreghionaljne spivrobitnyctvo v systemi transkordonnoji spivpraci [Euroregional cooperation in the system of cross-border cooperation] Socialjno-ekonomichni problemy suchasnogho periodu Ukrajiny. № 4, pp. 28-38.

5. Tymechko I.R. (2010) Orghanizacijno-ekonomichne zabezpechennja rozvytku prykordonnoji torghivli [Organizational and economic support for the development of cross-border trade]. (PhD Thesis) Ljviv : In-t reghionaljnykh doslidzhenj NAN Ukrajiny, pp. 24.

6. Pro transkordonne spivrobitnycztvo [About cross-border cooperation] : Zakon Ukrayiny [Law of Ukraine] vid 24.06.2004 № 1861-IV / Verhovna Rada Ukrayiny. Available at: https://zakon.rada.gov.ua/laws/show/1861-15 (accessed: 15 May 2020).

7. EGTS monitoring report 2018-2019. European Committee of the Regions. Available at: https://portal.cor.europa.eu/egtc/ ressources/Documents/CoR-EGTC-monitoring-report-final-study-2019.pdf (accessed: 10 May 2020).

8. Informacijnyj bjuletenj "Instrumenty ekonomichnogho rozvytku miscevykh ghromad: krashhi jevropejsjki praktyky u sferi transkordonnogho spivrobitnyctva" [Newsletter "Instuments of Local Communities' Economic Development: Best European Practices in the Sphere of Cross-Border Cooperation"]. Serija 1. Jevroreghiony, OJeS, JeOTS [Series 1. Euroregions, ECGs, EGTCs]. Available at: http://ird.gov.ua/irdp/p20190035.pdf (accessed: 21 April 2020).

Melnyk Olha, Pryveda Roksana

Lviv Polytechnic National University

\section{FORMS OF CROSS-BORDER COOPERATION IN UKRAINE: STATE AND PROSPECTS OF DEVELOPMENT}

In the article there are presented and described the forms of cross-border cooperation in Ukraine: cross-border clusters, cross-border industrial parks/zones, Euroregions, Euroregional cooperation associations, European Association for Territorial Cooperation, cross-border partnership, cross-border trade and cross-border projects. Peculiarities of functioning in cross-border space of Ukraine are distinguished. The advantages and disadvantages of the forms of cross-border cooperation functioning are revealed and the current state of development of cross-border cooperation on the territory of Ukraine is assessed. Undoubtedly, at the moment, cross-border cooperation is a lever for the development of border regions, which in turn creates a favorable basis for solving socio-economic problems that are present in border regions and strengthens Ukraine's integration processes into the European Union. The analysis of theoreticalmethodological and practical aspects of cross-border cooperation and its forms of functioning in the scientific works of native authors was carried out. The study of research also presents the principles, on the basis of which new forms of cross-border cooperation are operating, regulatory and legal framework of their activities. The subjects of crossborder cooperation may be territorial communities, local governments of Ukraine, which interact with the relevant authorities of neighboring states within the agreements on cross-border cooperation. And participants in cross-border cooperation are individuals or legal entities, united territorial communities that are directly involved in cross-border cooperation. Of course, at the moment, cross-border cooperation is a lever for the development of border regions, which in turn creates a favorable basis for solving socio-economic problems that exist in border regions and strengthens Ukraine's integration processes into the European Union. The purpose of the state policy of Ukraine on the development of cross-border cooperation is to create new forms of cross-border cooperation for more effective functioning and management of the processes of such cooperation. As a result of the research, the authors distinguished the most effective and prospective forms of cross-border cooperation in Ukraine. With new forms of cross-border cooperation in Ukraine can continue develop its border territories, projects and programs are implementing and improving economic relations with neighboring countries and integration processes facilitate including Ukraine in the European Union. Each of these forms has certain advantages and disadvantages, but the prospects for their operation are quite reliable for Ukraine and the development of its regions and border areas.

Key words: cross border cooperation, cross border space, Euroregional cooperation, development of Euroregions, forms of cross border cooperation.

JEL classification: F02 